\title{
CONFERENCE OF ENGINEERS AND SURVEYORS TO COUNTY ANI) OTHER SANITARY AUTHORITIES.
}

\section{ADDRESS}

By E. Pinelel IIoolex, Assoc.M.Inst.U.E.

PRESIDENT OE THE CONFEREXCK.

(Menibr.)

Havisg accepted the lonour offered me by the Sanitary Institute of presiding over your Section of this Congress, I have the grcatest pleasure in welcoming you to this charming, historic, and beautiful town. I most sincerely hope that your visit here will add a few liappy hours to your busy lives, and that the mutual intercourse, and opinions expressed, will be of interest and value not only to ourselves, but those who employ us.

I have had rery considerable difficulty in choosing for my adchess a theme that has not already been well worn and more ably discoursed upon than any with which I am able to entertain you, but the very fact of my having found this difficulty has in itself given me a text. I therefore propose with your indulgence to say a few words on the subject of "Some of the difficulties of Public Life, especially in regard to the position of a Surreyor under one or otler of the present Councils."

The youth entering the office of an Engineer fresh from school, too of ten dreams of, and looks forward to, a grand free and easy, hajpy-go-lucky, do-as-you-please life, with little or no cares or worries, a fairly decent salary, and a life appointment. How rudely are his dreams and fancies shaken, if he from the first takes any interest in his work. How quickly he finds out how many eager, strugrgling men lie has to compete with, how he must work and strive if he wishes to place lis foot on the proverbial bottom rung of the larlder, and even then what anxious worrying moments he has in store before he feels he has commenced his career. Think back awhile! Is there a man in this room who conld look bark 
and feel comfortable even now in thinking of the ireary waiting time, before he was "carning anything"? How devoutedly have we all wished we had learned more during our pupilage or secured the interest of $\mathrm{Mr}$. Blank, who could have helped us just now when we most wanted help. Then carry your mind to the anxious time when "selected" for an appointment where "canvassing is prohibited"; you are one of seven "selected," and going through the weary wait outside the Committee Room, feeling and finding out your chances of success are lessening every time you speak to anyone, though possibly happy in the thought yon have honourably obeyed instructions and not canvassed, whilst you hear on all sides that a local man, the son of a builder, a broken down farmer, or even a member of the Cunncil, is also "selected," and has not so honourably obeyed instructions. But these are only early difficulties, and as time goes on, one looks back and smiles at the thought of how our best hopes were then dashed to the ground by being informed by the Clerk of the Council, with a pitiful look of commiseration on his face, that he is "sorry to inform you, gentlemen, none of you are elected, but Mr. Jones (the local builder and ex-member of the Council, lately retired) is elected. If you will let me have a note of your third class fare (no, we cannot allow cabs!), the amount shall be forwarded to you after the next meeting in a month's time." But I am thankful to think this, which was a very common result twenty years ago, is but seldom met with nowadays, and the greatest difficulty that arises from the foregroing position is the difficulty of finding a man, a very few years after, able and willing for the small pittance of ten offered, to undertake the work of undoing all that the then elected man las blundered into, either throngh lack of knowledgre, or the bullying of those "friends" who elected lim to an office he was totally unfitted for, a few years before, and now consigned by them to an carly grave or the workhouse, because at last he had ventured to point out that, which cren lie had been able to see was rascally wrong. and so proroked their ire. Look back again, any of you who can remember those early days when you appeared before a Bourd and finally upset the arrangement of Mr. Builder's election, by being anjointed br a bare majority of men who felt you were the man, who slould be appointed, in spite of all outside pressure and local interests, then ponder for a moment over the feeling that makes you blush for your manhood now when you think of what you had to put up with from certain members of that minority. Happily, the writer's lot has been differently situated, but in no position better than a County Surveyor, in touch with Urban men, can this intolerable 
position be better linown or more sincerely commiserated witl. But let us pass these difficulties and turn to the difficulties met with when holding an appointment supposed to be of a remunerative character. How seldom dares one act with the independence one feels entitled to act, to be honest and true to one's own better nature. How often one's best motives are misconstrued or misunderstood, and rery often, after haviner acted to the very best of one's ability, does that "friend to all" the Local Press, commence its pleasing duties of pointing out -in large type-that "reckless extravagance and necilless wiste has been exercised, instead of the economy preached at the preceding election by our candilate." Then cone the minor stings of the anonymous correspondent, and the final heckling by the goaded Councillor who happens to know nothing of the matter complained of, but being returned by his fellow workingman, thinks it his right to ask Mr. Surveyor a few personal, and bordering on excessively rude questions, he is pleased to think his outside friends will appreciate, when they rear their half-penny paper; the said paper heading its columns; with large letters of a peculiarly irritating type. With this, as a minur experience of a minor Council, in official is supposed to mildly. submit to as part of the reward of a silary a few shillings per week better than his road foreman, and feel it is only " $\mathrm{Mr}$. .Jones doing his duty to the ratepayers;" and if you complain to any kindly member of your Council, you are told not to $h$. too thin skinimed, no harm is meant. To the established young Surveyor such troubles sit lightly, bnt to a young man with fine feelings the position mar be intolerable.

Again, the laws of our land wisely prevent any individual being a member of a Council and thereby interested in any contract being undertaken by him with this Council. There are contracts and contracts, but I know of no worse contract than that made by a man having been corrected, or made to carry out that which has been against his wishes or pocket, afterwards being allowed to take a seat on a Council, having previunsly openly stated that he has obtained his seat for the sole purpose of venting his spleen and endeavouring to upset the otticialwho has possibly been the innocent cause of his trouble, anul by obtaining his removal, grets his desired end and sares his indivichal pocket by either worrying the ofticial into resigning, or gatlering sufficient force around him to obtain his dismissal on quite amother ground of complaint, everyone else being quite aware of the real cause of this action.

The difficulties of early careers can only be too well remembered by most of us, and those who have sailed on the troublech sea, can but warmly fecl for those now passing over the unplea- 
sant waters, but when passed, the haven of rest is not quite reached, for public life as understood in comection with Local Government, is nerer a bed of roses. Troubles are constant, and lucky is the man who can steer throngl the greater, if he does not fall or fail through the minor ones.

The author will not travel further through the long vista of an average career, but content himself with a few remarlis on an average income in payment of these services that are expected to be so checrfully and uncomplainingly rendered by, at any rate, the Surveyor.

The majority of salaries on which a man is supposed to

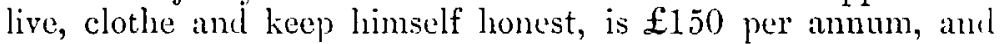
lucky is the man who finds lie is able to kecp single until his prospects are more settled. After a few rears of waiting, whilst possibly his district has doubled itself in size, and he has worked as he probably never will again, his salary is grumblingly increased to $\mathfrak{£} 200$ per year. He then sees a prospect of a home, a wife, and happier surroundings; at thirtyfive he may be in receipt of $\$ 350$ per ammum, but still his position compels him to keep his head as high as possible, and his conduct so straight, that he, to be above suspicion, must spend almost every shilling of his earnings, and thus has no possible chance of saving for a rainy day, for those who are now dependent upon him. But there is such a risk, and few who have not considered the question seem to realize it, ancl the author's opinion certainly favours it, that the early worry, the anxious and everlasting strain that a young man has to so through, too often weakens his constitution, and makes him unfitterl to sustain a severe illness, and this is the canse of the very many early collapses our Association of M Municipal and County Enginecrs has to record.

With these thoughts of the future, think what a grateful country does in return; it exclucles us from the benefits of superamuation, and has no means of helping our wires or children, if we have been mable to do anything ourselves for them. The aluthor can only urge all his hearers to strive unwards to the goal of all public service, viz., superammution, and whilst this is being striven for, he would warmly recommend and earnestly beg all those who can to help each otlier by doing their utmost to assist the efforts that are now being made to help the widows and orphans of those who have left us, without hiving been able to do anything for those who are left behind. The thoughts of leaving that little family unprovided for may ouly too possibly have been the cause of a terrible cleath-wrench when the horrors of the future have been vividly brought forward. This "difficulty" hats ahready been ably dealt with quite 
lately, and will be keenly in the mind of most hearers of the address of the Presilent of the Association of Municipal and County Engineers.

The author, as a remedy to all these woes, can only suggest that the Local Government Board should accept the Surveyor on the same footing as the Medical Officer of Health and Inspector of Nuisances, and so at any rate prevent his being clismissed at the caprice of those over him without any court of appeal, and then with superammuation in front and security of office at hand his lot would be happier, his worries less pungent, and his mind freer to combat with his daily duties and professional worries.

The difticulties dealt with liave been those of a melancholy nature, and my hearers, I fear, will rote I am gnilty of bringing the doleful side of life before them. No one can look back to a happier and brighter career than does the author of this address to-day, but the difticulty of being in too comfortable a position is one almost as embarrassing as that of the uncomfortable one already touched upon, and to those so happily situated, I would earnestly commend the positions of those not so favourably placed, and beg all to try and do their utmost to help each other, remembering that a little real help is worth endless sympathy. The opportunity of removing a few of the "difticulties" met with in a public career is bound to come to all, and I know of no better opportunity or one more likely to succed than the mutual help, to be met with at this and similar meetings. May the prescnt meeting have the success it cleserves, and may the papers rearl and the mutual advice given, be the means of all here spending a happy and enjoyable time, free from public worries or such like calles, and fit us to returu to our duties in a more happy and contented mind. 